\title{
RESPON PERTUMBUHAN BIBIT KELAPA SAWIT (Elaeis guineensis jacq) TERHADAP INTERVAL PEMBERIAN PUPUK HAYATI
}

\author{
Putu Wandika ${ }^{1)}$, Sukriming Sapareng*2), Sitti Maryam Yasin ${ }^{2)}$ \\ ${ }^{1)}$ Alumni Program Studi Agroteknologi Fakultas Pertanian, Universitas Andi Djemma Palopo \\ ${ }^{2)}$ Program Studi Agroteknologi Fakultas Pertanian, Universitas Andi Djemma Palopo \\ *)e-mail : miming.mlgke@gmail.com
}

\begin{abstract}
Ringkasan
Penelitian bertujuan mengetahui interval pemberian pupuk hayati bio nano yang terbaik pada pertumbuhan bibit kelapa sawit di pembibitan awal. Penelitian dilakukan dalam bentuk percobaan lapangan yang menggunakan Rancangan Acak Kelompok yang terdiri atas 5 perlakuan yaitu tanpa pemberian pupuk hayati, pemberian pupuk hayati tiap 1, 2, 3, dan 4 minggu. Masing-masing perlakuan diulang 3 kali dan terdiri atas 3 unit satuan percobaan sehingga terdapat 45 tanaman. Pemberian pupuk hayati bio nano tiap satu minggu memberikan pengaruh terbaik terhadap tinggi tanaman umur $1-3 \mathrm{BST}$, masingmasing $18.05 \mathrm{~cm}, 26.05 \mathrm{~cm}$ dan $35.55 \mathrm{~cm}$, jumlah daun yaitu 4,00, 5,11 dan 7,11 helai, dan diameter batang yaitu $3.88 \mathrm{~cm}, 7.33 \mathrm{~cm}$ dan $11.22 \mathrm{~cm}$, serta bobot yaitu 7,00 gram.
\end{abstract}

Kata kunci : bio nano, kelapa sawit, interval, waktu, pupuk hayati 


\section{RESPONSE OF GROWTH OF PALM OIL (Elaeis guineensis jacq) ON THE INTERVAL OF BIOFERTILIZER FERTILIZER}

The aim of this research is to find out the best interval of bio nano bio fertilizer application on the growth of oil palm seedlings in the initial nursery. The study was conducted in the form of a field experiment using a Randomized Group Design consisting of 5 treatments, namely without the provision of biological fertilizers, the provision of biological fertilizers every 1, 2, 3, and 4 weeks. Each treatment was repeated 3 times and consisted of 3 experimental units so that there were 45 plants. The application of bio nano bio-fertilizers every one week gives the best effect on plant height aged 1-3 BST, respectively $18.05 \mathrm{~cm}, 26.05 \mathrm{~cm}$ and $35.55 \mathrm{~cm}$, the number of leaves is 4.00, 5.11 and 7.11 strands, and diameter the stem is $3.88 \mathrm{~cm}, 7.33 \mathrm{~cm}$ and $11.22 \mathrm{~cm}$, and the weight is 7.00 grams.

Keywords: bio nano, palm oil, interval, time, biological fertilizer

\section{PENDAHULUAN}

Kelapa sawit (Elaeis guineensis jacq) merupakan tanaman dengan nilai ekonomis yang cukup tinggi karena merupakan salah satu tanaman penghasil minyak nabati, bagi Indonesia. Kelapa sawit memiliki arti penting karena mampu menciptakan kesempatan kerja bagi masyarakat dan sebagai sumber perolehan devisa negara. Sampai saat ini Indonesia merupakan salah satu produsen utama minyak sawit dunia selain Malaysia dan Nigeria (Fauzi, 2014). Bagi negara konsumen terutama negara yang telah maju, selalu menginginkan minyak sawit yang benar-benar bermutu. Permintaan tersebut cukup beralasan sebab minyak sawit tidak hanya digunakan dalam bahan baku dalam industri pangan saja, tetapi banyak industri nonpangan yang membutuhkan. Lagi pula, tidak semua pabrik kelapa sawit mempunya teknologi dan intalansi yang lengkap, terutama yang berkaitan dengan proses pengolahan minyak kelapa sawit (Pahan, 2015).

Produksi tanaman kelapa sawit pada tahun 2012 sekitar 26,5 juta ton, tahun 2013 sekitar 30,0 juta ton, tahun 2014 sekitar 31,5, tahun 2015 sekitar 32,0 dan tahun 2016 sekitar 32,5 ribu ton (Badan Pusat Statistik, 2014). Permintaan kelapa sawit yang meningkat menyebabkan produksi dan perluasan areal pertanaman kelapa sawit semakin meningkat. Dengan bertambahnya luas areal pertanaman kelapa sawit tersebut, maka diperlukan pengadaan bibit dalam jumlah besar dan berkualitas. Dalam usaha membudayakan kelapa sawit, masalah pertama yang dihadapi oleh pengusaha atau petani yang bersangkutan adalah pengadaan bibit. Kualitas bibit sangat menentukan produksi jenis komoditi ini (Setyatmidjaja, 2006).

Pembibitan merupakan salah satu faktor penentu keberhasilan budidaya kelapa sawit. Dalam pembibitan kelapa sawit dikenal dengan adanya "dauble stage". Pembibitan awal dilakukan selama 3 bulan dan membutuhkan naungan. Pembibitan awal bertujuan untuk mendapatkan tanaman yang pertumbuhannya seragam saat di pindahkan ke pembibitan utama. Pembibitan utama di lakukan untuk menyiapkan tanaman agar cukup kuat sebelum di pindahkan kelapangan (Semangun, 2008). Penggunaan pupuk hayati ini untuk tanaman tahunan/ perkebunan dapat mengurangi penggunaan pupuk dasar sebesar $30 \%$. Aplikasi pupuk hayati ini dapat memaksimalkan produksi. Hasil penelitian Kiswanto (2008) selama 
satu tahun tanaman kelapa sawit menunjukkan bahwa aplikasi pupuk hayati ini dapat meningkatkan produksi tanaman 24-33\% dengan konsentrasi 0,5\% setiap dua minggu sekali. Untuk melihat pertumbuhan kelapa sawit yang baik pada masa pembibitan awal, maka perlu dilakukan suatu penelitian yang bertujuan untuk mendapatkan konsentrasi yang optimal dan frekuensi pemberian pupuk hayati bio nano yang terbaik pada pertumbuhan bibit kelapa sawit dipembibitan awal.

\section{BAHAN DAN METODE}

\section{Waktu dan Tempat}

Penelitian dilaksanakan dalam bentuk percobaan lapangan selama empat bulan mulai November 2018 sampai Februari 2019. Penelitian dilaksanakan di Kelurahan Tomarundung, Kecamatan Wara Barat Kota Palopo.

\section{Bahan dan Alat}

Bahan-bahan yang digunakan dalam penelitian ini adalah bibit kelapa sawit varietas Tenera, pupuk kandang, pupuk bio nano, tanah, pasir, polibag ukuran $20 \times 30 \mathrm{~cm}$. Alat yang digunakan yaitu cangkul, ember, ayakan tanah, parang, gembor, sprayer, mistar, meteran, kamera dan alat tulis menulis.

\section{Metode Penelitian}

Penelitian ini dilakukan dalam bentuk percobaan lapangan yang menggunakan Rancangan Acak Kelompok (RAK) yang terdiri atas 5 perlakuan yaitu :

$\mathrm{P}_{0}=$ Tanpa Pemberian pupuk hayati (kontrol)

$\mathrm{P}_{1}=$ Pemberian pupuk hayati tiap 1 minggu

$\mathrm{P}_{2}=$ Pemberian pupuk hayati tiap 2 minggu

$\mathrm{P}_{3}=$ Pemberian pupuk hayati tiap 3 minggu

$\mathrm{P}_{4}=$ Pemberian pupuk hayati tiap 4 minggu

Masing-masing perlakuan diulang 3 kali dan terdiri atas 3 unit satuan percobaan sehingga terdapat 45 tanaman.

\section{Pelaksanaan Penelitian}

Media tanam yang digunakan adalah campuran tanah top soil dan pupuk kandang dengan perbandingan $1: 1$. Media yang telah tercampur secara merata dimasukkan ke dalam polibag kemudian disusun dan disiram sampai jenuh lalu dibiarkan selama seminggu. Perlakuan pemberian pupuk hayati bio nano dengan dosis $7 \mathrm{ml}$ dicampurkan 14 liter yang disemprotkan ke tanaman dengan interval pemberian sesuai perlakuan.

\section{HASIL DAN PEMBAHASAN}

Pemberian pupuk hayati setiap minggu (P1) menghasilkan bibit kelapa sawit tertinggi, jumlah daun terbanyak, dan diameter batang terbesar pada umur 1, 2 dan 3 bulan setelah tanam (BST) (Tabel 1) 
Tabel 1. Tinggi tanaman $(\mathrm{cm})$, jumlah daun (helai) dan diameter batang $(\mathrm{cm})$ bibit kelapa sawit pada umur $1-3$ BST

\begin{tabular}{crrrrrrrrr}
\hline \multirow{2}{*}{ Perlakuan } & \multicolumn{3}{c}{ Tinggi Tanaman $(\mathrm{cm})$} & \multicolumn{3}{c}{ Jumlah Daun (helai) } & \multicolumn{3}{c}{ Diameter Batang $(\mathrm{cm})$} \\
\cline { 2 - 10 } & 1 BST & 2 BST & 3 BST & 1 BST & 2 BST & 3 BST & BST & 2 BST & 3 BST \\
\hline P0 & $7,16^{\mathrm{d}}$ & $13,13^{\mathrm{d}}$ & $19,61^{\mathrm{d}}$ & $2,55^{\mathrm{c}}$ & $3,44^{\mathrm{c}}$ & $4,22^{\mathrm{b}}$ & $1,89^{\mathrm{b}}$ & $3,61^{\mathrm{c}}$ & $5,66^{\mathrm{d}}$ \\
P1 & $18,05^{\mathrm{a}}$ & $26,05^{\mathrm{a}}$ & $35,55^{\mathrm{a}}$ & $4,00^{\mathrm{a}}$ & $5,11^{\mathrm{a}}$ & $7,11^{\mathrm{a}}$ & $3,88^{\mathrm{a}}$ & $7,33^{\mathrm{a}}$ & $11,22^{\mathrm{a}}$ \\
P2 & $14,57^{\mathrm{ab}}$ & $22,88^{\mathrm{b}}$ & $29,83^{\mathrm{b}}$ & $3,33^{\mathrm{b}}$ & $4,77^{\mathrm{ab}}$ & $5,66^{\mathrm{ab}}$ & $2,88^{\mathrm{ab}}$ & $5,55^{\mathrm{b}}$ & $9,33^{\mathrm{ab}}$ \\
P3 & $11,77^{\mathrm{bc}}$ & $20,61^{\mathrm{b}}$ & $27,44^{\mathrm{bc}}$ & $3,11^{\mathrm{b}}$ & $4,11^{\mathrm{bc}}$ & $4,22^{\mathrm{b}}$ & $2,55^{\mathrm{b}}$ & $5,05^{\mathrm{bc}}$ & $8,44^{\mathrm{bc}}$ \\
P4 & $9,16^{\mathrm{cd}}$ & $17,06^{\mathrm{c}}$ & $23,33^{\mathrm{cd}}$ & $2,66^{\mathrm{c}}$ & $3,89^{\mathrm{c}}$ & $4,55^{\mathrm{b}}$ & $2,22^{\mathrm{b}}$ & $4,50^{\mathrm{bc}}$ & $6,83^{\mathrm{cd}}$ \\
\hline NPBNJ $_{0.01}$ & 4,12 & 3,01 & 4,51 & 0,30 & 0,62 & 1,52 & 1,02 & 1,61 & 2,21 \\
\hline
\end{tabular}

Keterangan : Nilai rata-rata yang diikuti oleh huruf dan kolom yang sama berarti berbeda tidak nyata pada taraf uji $\mathrm{BNJ}_{0,01}$.

Data pengamatan tinggi tanaman yang diamati setiap bulan hingga 3 BST, diketahui bahwa perlakuan pupuk organik hayati menunjukkan pengaruh yang nyata (Tabel 1). Hal ini karena efek penggunaan pupuk hayati, dimana pengaruh suhu rumah kaca yang tinggi dapat diminimalisir karena kemampuan bahan organik menjaga kelembaban tanah dan hara yang terkandung pada pupuk organik bersifat lambat tersedia. Hasil penelitian Waspodo dkk (2013) menunjukkan hasil yang paling berpengaruh pada pertumbuhan vegetatif bibit kelapa sawit pada pertumbuhan awal.

Hasil analisa statistik BNJ $1 \%$ terhadap data pengamatan jumlah daun hingga 3 BST, menunjukkan pengaruh nyata. Hal tersebut menunjukkan bahwa permberian pupuk hayati setiap minggu menghasilkan jumlah daun terbaik. Kandungan bahan organik juga berperan sebagai sumber dan makanan mikrob tanah sehingga dapat meningkatkan aktifitas mikrob tanah dalam menyediakan unsur hara bagi tanaman (Mangoensoekarjo, 2007). Demikian juga peningkatan pertumbuhan diameter batang pada pemberian pupuk hayati setiap minggu dan setiap dua minggu relatif berbeda tidak nyata. Pemberian unsur kalium dan fosfor akan menyebabkan tanaman tidak mudah roboh, diameter batang membesar, pembuluh xylem dan floem tidak mudah rusak, sehingga memperlancar pengangkutan mineral dan fotosintat. Pengukuran diameter bonggol tanaman dilakukan untuk mengetahui sejauh mana perlakuan yang diaplikasikan pada media tanam bibit kelapa sawit dapat mendukung pertumbuhan keragaan tanaman sebelum dipindah tanam kelapangan karena melalui tahap pembibitan sesuai standar teknis diharapkan dapat dihasilkan bibit yang baik dan berkualitas (Agus, 2013)

\section{Bobot Kering (gram)}

Pemberian pupuk hayati setiap minggu (P1) menghasilkan bobot kering bibit kelapa sawit tertinggi pada umur 3 BST (Tabel 2). 
Tabel 2. Bobot keting bibit kelapa sawit pada umur 3 BST (gram)

\begin{tabular}{ccc}
\hline Perlakuan & Bobot Kering (gram) & NPBNJ $_{0,01}$ \\
\hline P0 & $2,67^{\mathrm{b}}$ & \\
P1 & $7,04^{\mathrm{a}}$ & 3,1 \\
P2 & $4,33^{\mathrm{ab}}$ & \\
P3 & $4,02^{\mathrm{b}}$ \\
P4 & $3,67^{\mathrm{b}}$ & \\
\hline
\end{tabular}

Keterangan : Nilai rata-rata yang diikuti oleh huruf dan kolom yang sama berarti berbeda tidak nyata pada taraf uji $\mathrm{BNJ}_{0,01}$.

Biofertilizer (Mikroba Fungsional) yang terdapat dalam bio nano. Biofertilizer dilengkapi dalam pupuk organik baik sebagai agensia fermentasi maupun sebagai materi perkaya pupuk organik. Biofertilizer adalah kombinasi beberapa jenis mikroba fungsional yang dapat berfungsi sebagai agen fermentasi dan sebagai pupuk hayati yang dapat bekerja dalam tanah dan membantu pertumbuhan tanaman, serta meningkatkan ketahanan tanaman terhadap penyakit dan meningkatkan kesehatan dan produktifitas tanaman.

Pemberian pupuk hayati tiap 1 minggu (P1) memberikan hasil paling berat, disebabkan kandungan pupuk hayati bio nano lebih optimal dibandingkan dengan perlakuan yang lainnya. Bobot kering tanaman sangat ditentukan oleh kesuburan tanaman, semakin tinggi tanaman semakin banyak jumlah daun yang terbentuk dan semakin panjang akar yang dihasilkan dengan demikian bobot tanaman juga akan bertambah berat (Novizan, 2007). Perlakuan pupuk hayati $1600 \mathrm{~g} / \mathrm{bibit}$ dengan pupuk majemuk NPK $20 \mathrm{~g} / \mathrm{bibit}$ menghasilkan bobot kering tajuk bibit kelapa sawit terbaik (Ariyanti dkk, 2017).

\section{KESIMPULAN}

Pemberian pupuk hayati bio nano tiap satu minggu memberikan pengaruh terbaik terhadap tinggi tanaman umur 1 - 3 BST, masing-masing $18.05 \mathrm{~cm}, 26.05 \mathrm{~cm}$ dan 35.55 $\mathrm{cm}$, jumlah daun yaitu 4,00, 5,11 dan 7,11 helai, dan diameter batang yaitu $3.88 \mathrm{~cm}, 7.33$ $\mathrm{cm}$ dan $11.22 \mathrm{~cm}$, serta bobot yaitu 7,00 gram.

\section{DAFTAR PUSTAKA}

Agus., 2013. Pengaruh Pemberian Pupuk Hayati (Biofertilizer) dan Media Tanam yang Berbeda pada Pertumbuhan dan Produksi Tanaman Kelapa Sawit. Jurnal Sains Dan Ternologi, UNAIR.

Ariyanti M,, Natali G., Suherman C., 2017. Respons Pertumbuhan Bibit Kelapa Sawit (Elaeis guineensis Jacq.) terhadap Pemberian Pupuk Hayati dan Pupuk Majemuk

NPK. Jurnal Agrikultura, 28 (2) : 64-67. 
Fauzi., 2014. Kelapa Sawit. Penerbit Swadaya, Jakarta.

Kiswanto., 2008. Teknologi Budidaya Kelapa Sawit. Balai Besar Pengkajian dan Pengembangan Teknologi Pertanian. Badan Penelitian dan Pengembangan Pertanian. http://cybex.deptan.go.id (29 Februari 2018).

Mangoensoekarjo., 2007. Manajemen Tanah dan Pemupukan Budidaya Perkebunan. Gadjah Mada University Press. Yogyakarta.

Pahan., 2015. Penduan Lengkap Kelapa Sawit (Elaeis guineensis jacq). Penerbit Swadaya, Jakarta.

Semangun., 2008. Manajemen Agribisnis Kelapa Sawit. Gajah Mada Universitas, Yogyakarta.

Setyatmidjaja., 2006. Budidaya Tanaman Kelapa Sawit. Kanisius. Yogyakarta.

Waspodo A., Nurzaman M., Budiono R., 2013. Pengaruh Pemberian Berbagai Dosis Pupuk Hayati dan Pupuk NPK terhadap Pertumbuhan Bibit Kelapa Sawit (Elaeis Guineensis Jacq) pada Tahap Pre Nursery. Jurnal Biotika, 11 (1) : 69-75. 